\title{
Variation of dietary fibre content and gel-chromatography profile of the fruit pulp of four morphologically different fruit types of palmyrah
}

\author{
L. Gayathri Pathberiya*, N. Sevvandi Senadheera and E. R. Jansz \\ Department of Biochemistry, University of Sri Jayawardenepura, Gangodawila, Nugegoda.
}

Revised: 05 November 2006 ; Accepted: 15 December 2006

\begin{abstract}
Palmyrah (Borassus flabellifer) is a common plant in Sri Lanka. Its fruit pulp (PFP) has active constituents, which are steroidal saponins called flabelliferins. Although these flabelliferins may play a minor role in the hypocholesterolaemic effect, it is clear that other important factors are also involved. This study investigates the content of the soluble and insoluble dietary fibre and some characteristics of the soluble dietary fibre from the pulp of four common types of palmyrah. Results showed that dietary fibre content was high $(12.3 \%$ to $24.3 \%$ Dry weight) but type dependent. The pectin and soluble dietary fibre of the four types showed distinct elution patterns on sepharose (CL-2B-300) gel-chromatography indicating different molecular weight profiles.
\end{abstract}

Keywords: Dietary fibre, palmyrah fruit pulp, pectin, sepharose gel chromatography.

\section{INTRODUCTION}

The palmyrah palm (Borassus flabellifer) is widely distributed in the arid zones of Sri Lanka, South East Asia and East Africa. Palmyrah fruit pulp (PFP) is consumed widely in Sri Lanka as dried fruit leather, jams, beverages, etc. Palmyrah cultivars can be categorized into four common types according to the morphology of fruits that have been described previously in detail ${ }^{1}$. It has been shown that depending on the fruit type, the profiles of bioactive compounds in PFP e.g. flabelliferins (steroidal saponins) vary ${ }^{1}$. Past studies have shown that the PFP contains pectins with methoxy value of $3.4^{2}$. Pectins that are classified as soluble fibres ${ }^{3}$ are polymers of galactouronic acid together with methoxy/ethoxy derivatives of galactouronic acid and are of commercial value in the food industry. Dietary fibre which comprises soluble dietary fibre (SDF) and insoluble dietary fibre (IDF) is well known as a serum cholesterol lowering agent ${ }^{3}$ and has many other nutritional benefits such as lowering glycaemic index and the incidence of large bowel disease.
The objectives set for this study were to quantify the soluble and insoluble dietary fibre contents in PFP of the four common morphologically different fruit types and to determine whether there is any variation in their pectin and soluble fibre profiles by subjecting them to sepharose-gel chromatography.

\section{METHODS AND MATERIALS}

Palmyrah fruits $(\mathrm{n}=80)$ were collected from Kalpitiya in the North-West of Sri Lanka and separated into four common types ${ }^{1}(n=10-30)$ given below, bagged separately and transported to Nugegoda (nearly $200 \mathrm{~km}$ away) where they were stored at $-20^{\circ} \mathrm{C}$.

Type I: Colour, black, pericarp rough with brown longitudinal striations, distal side black ${ }^{1}$;

Type II: Colour black, pericarp smooth and no striations, distal side three orange spots ${ }^{1}$;

Type III: Colour black and orange longitudinal stripes, pericarp smooth, distal side black and orange stripes ${ }^{1}$;

Type IV: Colour orange, pericarp smooth ${ }^{1}$.

Within one week of collection, PFP was extracted from fruits manually ${ }^{4}$ using water in the ratio of $2: 1(\mathrm{v} / \mathrm{w})$ with respect to PFP. The pulp was stored in high-density polyethylene bags at $-20^{\circ} \mathrm{C}$. The moisture content of PFP was determined in duplicate using the AOAC and Dean and Stark method ${ }^{5}$. The extraction of dietary fibre (insoluble and soluble) was carried out in duplicate using the enzymic method described by Asp et al. ${ }^{6}$, from PFP $(10 \mathrm{~g})$ of each type, sampled form homogenous samples of 2-3 kg obtained from 10-20 fruits each. Soluble dietary fibre (SDF) was isolated following the same procedure i.e 
by methanol precipitation, after the insoluble dietary fibre was separated The filtration of SDF precipitate was carried out using filter paper instead of sintered glass crucibles and the incineration step of the Asp ${ }^{6}$ method was omitted since the SDF had to be solated and could not be burned off The SDF was freeze dried and werghed The SDF samples $(005-0 \mathrm{lg})$ were dissolved in phosphate buffer $(01 \mathrm{M})$ in volume of $2 \mathrm{ml}$ and introduced into the Sepharose column (CL-2B-300) of $20 \mathrm{ml}$ (height $=21 \mathrm{~cm}$ ) The same phosphate buffer was used as the eluting solvent Fractions were collected and freeze dried The soluble fibre of each fraction was determined gravimetrically after freeze-drying (subtracting the weight of the buffer blank from each fraction) The freeze-dried fractions dissolved in water $(025 \mathrm{ml})$, were then assayed by the carbozole reaction, after primary and secondary hydrolysis with $\mathrm{H}_{2} \mathrm{SO}_{4}{ }^{7}$

\section{RESULTS AND DISCUSSION}

The insoluble and soluble dietary fibers were determined separately and in duplicate Soluble dietary fiber of type I, II, III and IV were $90,106,55$ and $80 \%$ dry weight PFP respectively while the insoluble dietary fiber for the four types were $88,119,68$ and $163 \%$ dry weight PFP There was also a difference in the visual appearance of SDF of the 4 types Type I gel-like, Type II sof,cloudy Type III gel-like, Type IV gel-like, cloudy

Pectin content of types I, II, III and IV were 7 2,7 8,53 and $72 \%$ dry weight of PFP respectively, showing that pectins comprise the major fractions of soluble dietary fibre, in each case Figure below shows the profiles of pectins obtained from the sepharose column As expected with carbohydrate polymers the pectins showed polydispersity Type I showed the lowest elution volume fraction and type II and III distinctly shifted to higher elution volume (lower molecular werght) Blue dextran molecular weight about 2 million eluted at $8-10 \mathrm{ml}$

Pectin content was 5 3-7 8\% This is more than the amount reported previously (4-6\% dry werght ${ }^{2}$ ) The better range of sampling adopted in this study, gives a more sound basis for pectin content of the common PFP This is important, as isolated pectin is commercially valuable in food industry

Separation of pectin on sepharose column gel chromatography resulted in different elution profiles indicatıng that there is a varied distribution of molecular weight of pectuns in the different types The more gel like visual appearance could be due to the high molecular
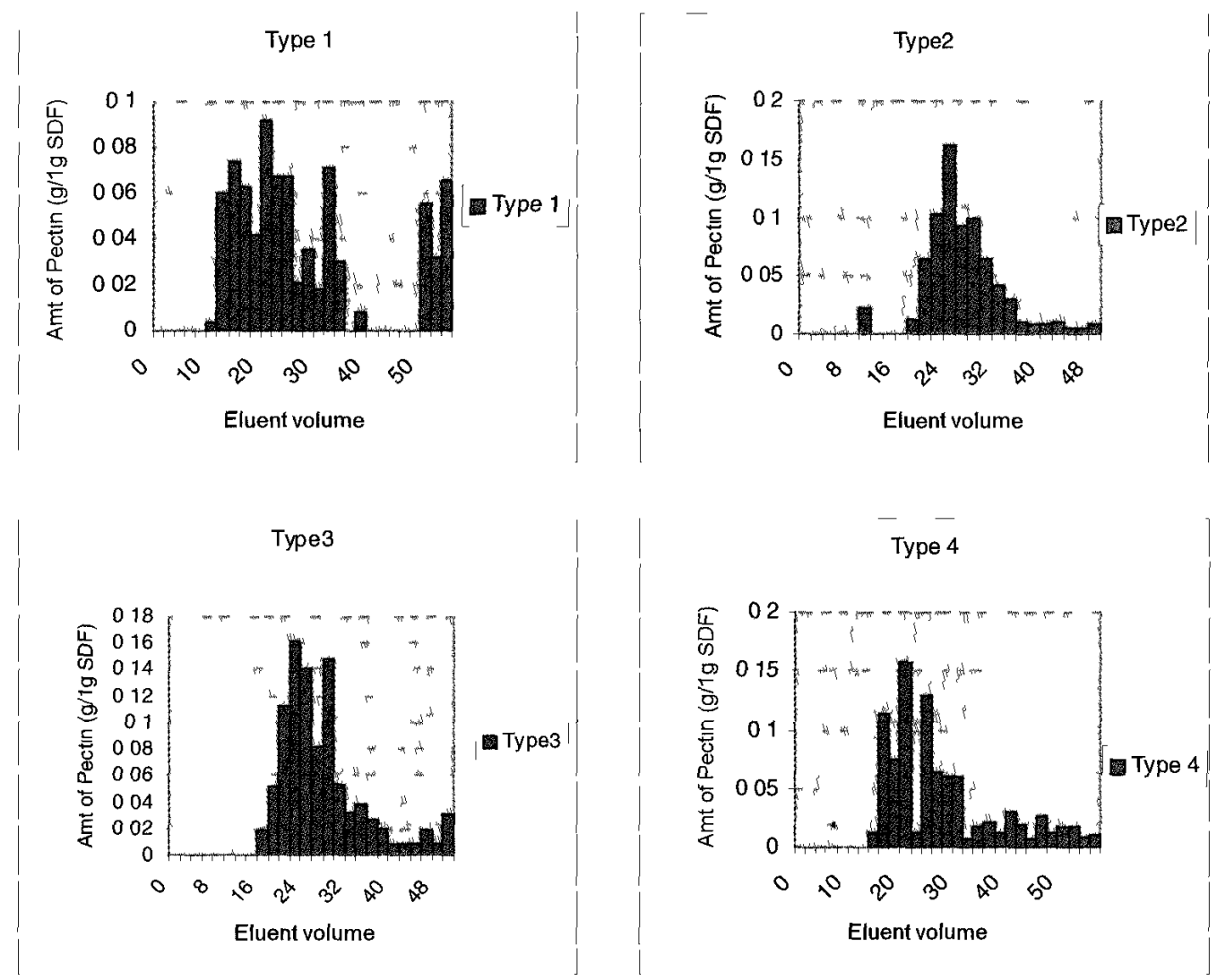

Figure. Pectin profiles of four common types of PFP 
werght molecules that are present in type I and type IV that have lower elution volumes and are highly viscous It was not possible to determine the molecular weight ranges as no monodisperse carbohydrate standards, except for blue dextran ( 2 million Da) was avallable Results indicated that type I had pectm molecules of MW 2 milhon

It is clear that high dietary fibre (both SDF and IDF) can result in lowering of cholesterol ${ }^{3}$ This will be significant as PFP is used as a food Highly viscous pectıns also have a major effect on bindıng bile salts and preventing their reabsorption, a known serum cholesterol lowering effect ${ }^{8}$ The difference observed in SDF, IDF and pectin could, to a certain extent, explain the varied lowering of serum cholesterol in mice fed with $10 \%$ PFP of these four types of PFP compared to the controls ${ }^{9}$

\section{Acknowledgement}

The authors thank IPICS, Uppsala, Sweden for the grant SRI 07

\section{References}

1 Ariyasena D D, Jansz E R \& Abeysekera A M (2001) Some studies directed at increasing the potential use of palmyrah (Borassus flabellfer L) frut pulp Journal of the Sclence of Food and Agrtculture 81 1347-1352

2 Senanayake N, Nikawela J K \& Jansz E R (1992) Some studies directed at the inegration of constituents of palmyrah fruit pulp Proceedings of Annual Session of the Srl Lanka Associaton for Advancement of Science 48 (1) 119

3 Wikramanayake T W (1996) Food \& Nutrition Hector Kobbakaduwa Agrarıan Research and Training Institute Colombo, Srı Lanka $3^{\text {rd }}$ Edition pp 141-148

4 Anyasena D D , Jansz E R , Jayesekara S , Abeysekara A M (2000) Inhibitory effect of bitter principles of palmyrah (Borassus flabellifer $\mathrm{L}$ ) fruit pulp on the growth of mice Journal of the Science of Food and Agnculture 80 1763-1766

5 AOAC (1984) Official Methods of Analysis $14^{\text {th }}$ Edition Vol VI 004, Association of Official Analytical Chemists

6 Asp N G, Hallmerh C G \& Siljestrom M (1983) Rapid Enzymatic assay for insoluble and soluble dietary fibre Journal of Agrtculture and Food Chemistry 31 476-82

7 Dekker R F H \& Richards G N (1972) Determination of pectic substances in plant material Journal of Sclence of Food and Agriculture 23 475-483

8 Miettınen T A, Tarpila S (1977) Effect of pectın on serum cholesterol, fecal bile acids and biliar in normolipidemic and hyperlipidemic individuals Clinical Chemistry Acta 79 (2) 471-7

9 Pathberiya L G (2005) The hypocholesterolaemic effect, in-vitro antioxidant capacity and the carotenoids of palmyrah fruit pulp $M$ phil Thesis, University of Srı Jayawardenepura, Nugegoda 